\title{
Filling In the Missing Link Between Universalism and Democracy: The Case of Costa Rica
}

\author{
Juliana Martinez Franzoni \\ Diego Sánchez-Ancochea
}

\begin{abstract}
This article explores a missing link in the recent literature on the formation of social policies: that between democracy and universalism, one desirable yet elusive feature of these policies. We base our argument on a case study of Costa Rica, the most successful case of universalism in Latin America. We proceed by first depicting Costa Rica's peculiar policy architecture, based on the incremental expansion of benefits funded on payroll taxes. Then we reconstruct the policy process to stress the key role played by technopoliticians in a democratic context. Backed by political leadership and equipped with international ideas, technopoliticians drove social policy design from agenda setting to adoption and implementation. Third, we argue that key aspects of the policy architecture established in the early 1940s were fundamental building blocks for a distinctive and seldom explored road to universalism. We conclude considering contemporary implications.
\end{abstract}

\begin{abstract}
A growing body of literature highlights the contribution of democracy to the enactment of universal social policies - understood as those that reach the entire population with similar, generous transfers and high-quality services - in Latin America and other peripheral countries. Electoral competition encourages all parties to offer broad-based benefits that simultaneously reach the poor and the middle class (Haggard and Kaufman 2008; McGuire 2010; Pribble 2013). ${ }^{1}$ Yet few democratic countries in the periphery have developed universal social policies. Chile and Uruguay, for example, had secured universal coverage in health and pensions by the 1970s, but with asymmetric benefits for different groups. Why have democratic arrangements sometimes led to universal social policies but more often have not?

We explore the missing link between democracy and universalism through the case of Costa Rica, which became "the closest case of a universalistic, egalitarian social state" (Filgueira 2007, 144) and the only one to "accomplish universalization of social security coverage, integrating social assistance with social security" (Sand-
\end{abstract}

Juliana Martínez Franzoni is an associate professor and researcher at the Instituto de Investigaciones Sociales, University of Costa Rica. juliana.martinez@ucr.ac.cr. Diego SánchezAncochea is an associate professor at the University of Oxford. diego.sanchezancochea@sant.ox.ac.uk 
brook et al. 2007, 40). Social insurance in Costa Rica was founded in 1941 with two unique features: it was a unified system, which included all workers (and later their families) with the same entitlements; and it first incorporated the urban lowerincome groups and only later the higher-income earners (in what we call a "bottomup" expansion). Unlike other Latin American countries where high-income groups (and the military) had premier access to benefits and vetoed their expansion to the poor, in Costa Rica these two features created incentives for the gradual universalization of social insurance-through legacies, as rigorously addressed by Pribble (2013) and others in the Latin American context.

Where did this unique architecture come from? How did social insurance expand over time in a universalistic fashion? We argue that democratic institutions and socially conscious politicians provided technopolitical actors involved in transnational policy networks with political space to shape the universal features of social insurance. These technopoliticians, not political parties, business elites, or trade unions, initially made social insurance a top political priority and later shaped its main features. While the absence of powerful veto actors made their task easier, technopols also played a role in managing the weak opposition that did exist. Once the new social security was in place, the bureaucratic institutions and architecture of the system became powerful legacies shaping the path toward universalism.

This article begins by engaging with the literature on social policy in Latin America and highlighting the missing link between democratic institutions and specific universalistic outcomes. Then it provides a complementary explanation based on a qualitative analysis of primary official and newspaper sources. By considering the unique features of social insurance, we show the benefits of Costa Rica's architecture. By paying careful attention to the process of policy formation, we offer a rich, empirical picture of the actors and ideas involved. By concentrating on the foundational moment of policy, we trace key influences on Costa Rica's subsequent trajectory.

\section{Missing LiNKS IN THE EXPLANATION of Universalism in the Periphery}

Latin America, like other regions in the periphery, historically struggled to develop universal social policies. In most countries coverage was low, benefits were poor, and quality was lacking. Argentina, Chile, Costa Rica, and Uruguay were significant exceptions: they all secured high coverage in social insurance with relatively good services and generous transfers. By the early 1980s in those four countries, social spending as a percentage of GDP was between 12.2 percent and 15.5 percent. Pensions reached between 61 percent and 84 percent of the active population in Chile and Uruguay, respectively, and healthcare coverage ranged between 48 percent of Uruguayans and 84 percent of Costa Ricans. By contrast, the group of agrarian, nonindustrialized countries in Latin America spent only 5.9 percent of GDP and had pension and healthcare coverage of 21.8 percent and 11.4 percent (Huber and Stephens 2012). 
Scholars largely agree that democracy plays a critical role in explaining the four successful cases of broad coverage. According to Filgueira (2007, 141), "early social state formation is highly correlated with early democratic experiments." Social insurance expanded in Argentina and Uruguay under democratic rule during the 1910 s and 1920s. Chile's founding push took place under the authoritarian rule of President Carlos Ibáñez, but the subsequent expansion took place under democracy. Electoral competition forced all parties to compete for the median voter and thus to incorporate as many people as possible into social policy (McGuire 2010). Democratic institutions also created space for left-wing political parties (in Chile and to a lesser extent in Uruguay) with more progressive social agendas. Huber and Stephens (2012) found that Latin American countries where left-wing parties generally prevailed were more likely to stress spending on health and education-which tend to be universally provided and more redistributive in their results-rather than on social insurance.

Costa Rica is no exception to this pattern. In the 1940s, electoral pressures led the newly elected President Rafael Angel Calderón Guardia to respond to the "social question" and push for social security (Lehoucq 2010; Molina 2008). The later expansion of pensions and health during the 1950s, 1960s, and 1970s has been explained by the dominance of a social-democratic party, the Partido de Liberación Nacional (PLN), which, every four years, faced intense electoral competition from and alternated office with conservatives.

Yet in Argentina, Chile, and Uruguay, democracy-driven universal coverage went hand in hand with unequal benefits across occupational groups. Uruguay by 1967 had nine pension funds, including those for civil servants, and nine autonomous health insurance funds for workers in different manufacturing activities (Mesa-Lago 1978). Also, in exchange for a monthly premium, large parts of the middle class received services from mutual insurance healthcare plans, which spent 3.1 times more resources per person than the public system (Mesa-Lago 1978). Argentina created separate funds for civil servants (founded in 1906), railway workers (1919), utility workers (1921), bank employees (1923), and several other groups (Lewis and Sherlock 2009). Each fund granted different benefits, and efforts to unify them during the late 1960s and 1970s failed (Huber and Stephens 2012). In Chile, social insurance involved more than ten different funds, with entitlements and obligations contained in more than two thousand legal texts (Mesa-Lago 1978; Segura-Ubiergo 2007). Not only did fragmentation inhibit universal outcomes, but in most instances, social spending deepened the socioeconomic segmentation created by the market (Haggard and Kauffman 2008).

Many scholarly explanations concerning the segmented character of social spending focus on the relative strength of interest groups. Mesa-Lago's 1978 pioneering work demonstrated that powerful pressure groups led four contrasting Latin American countries_-including Argentina and Chile, among the pioneers of social policy - to establish highly stratified social insurance. The state, the bureaucracy, and political parties responded, anticipated, or mediated demands from pressure groups with particularistic funds that included unequal benefits $(1978,9)$. Expan- 
sion of rights to new groups followed an "established pattern of leaving existing programs intact and creating new ones in addition" (Huber and Stephens 2012, 99).

Costa Rica departed from the high fragmentation found in the Southern Cone. By the late 1970s, most people had access to the same healthcare services provided by the Costa Rican Social Insurance Agency (Caja Costarricense del Seguro Social, CCSS) and benefited from a guaranteed pension. Although there were a few special programs for the public sector, everyone had access to the same hospitals, and the poor received means-tested, noncontributory pensions. Moreover, despite initial obstacles, by the mid-1980s, "Costa Rican agricultural workers had one of the highest degrees of coverage in Latin America” (Mesa-Lago 1985, 15).

A dominant explanation of Costa Rica's uniqueness relies on the absence of interest groups with particularistic agendas. Filgueira $(2007,145)$ highlights that "trade unions have always been weak." Pribble echoes this view and argues that Costa Rica's development of social policy “involved minimal mobilization" (2011, 205). Indeed, there is a remarkable difference between import substitution in the Southern Cone, which produced a rapidly growing urban working class, and Costa Rica's incipient industrialization, which inhibited the growth of an urban labor movement. However, by the 1930s, the basis for a labor movement was in place: over 67 percent of the economically active population in agriculture consisted of day laborers. By 1943, the first confederation of (Communist) unions was established, and by 1945, 22 percent of the economically active population was unionized. Moreover, some groups (i.e., teachers, judicial workers) were particularly powerful and more organized than others.

If the architecture of social policy basically reflects the strength and weakness of interest groups in democratic contexts, why did Costa Rica not adopt particularistic regimes among the most powerful occupations? And even if we accept Costa Rican interest groups' relative weakness, how do we explain the adoption of a specific type of social insurance system; namely, one that was unified rather than segmented along occupational lines?

To come up with a convincing explanation of why Costa Rica achieved broad coverage with similar, generous benefits for all while other countries did not, we must first consider the policy architecture; that is, which social groups were first incorporated into which policies. Argentina, Chile, and Uruguay all had special funds for privileged groups like military personnel and public servants since the very beginning. Following the European Bismarckian models-and the recommendations of the International Labor Organization (ILO) in the two decades following its founding in 1919-these programs were regarded as "the" path to building social insurance with wide coverage. By the 1940 s, a new consensus was emerging around unified social insurance, and Costa Rica became one of the first countries to establish a single system-one that created rather different legacies.

In short, the initial policy architecture and the legacies this architecture created are crucial mediating factors between democratic institutions and universal outcomes. In the absence of a social actor demanding the creation of a specific type of social insurance, we must explain what other factors may have shaped these features in the early 1940 s. 


\section{Our Alternative Explanation, SOURCES, AND METHODOLOGY}

To depict social insurance's primary features in its foundational stage, we rely on process tracing and determine the role of different actors in the policy process. Our goal is to collect a set of "causal-process observations" (Collier et al. 2010) to build a theory of the causal links between democracy, the design of universal architectures, and the actors behind the process.

To reconstruct conditions, actors, and ideas, we draw on two primary data sources: official records and newspapers. For official records we covered archival material in San José (in the National Archives and the Legislative Assembly), Geneva (ILO archives), and Santiago de Chile (Biblioteca Nacional de Chile). This material included partisan electoral platforms, two bills (from drafts exchanged as correspondence to the actual laws), four presidential state of the nation addresses, and letters between various actors. At the ILO, we consulted all correspondence between the Geneva office, the Costa Rican authorities, and the regional headquarters in Santiago de Chile in the early 1940s. In terms of newspapers, we focused on the period that immediately preceded and followed the adoption of social insurance and secured ideological diversity by gathering data from three main newspapers: Tribuna (progovernment), Diario de Costa Rica (non-Communist opposition), and Trabajo (Communist opposition).

We often contrast and complement our analysis with Rosenberg's pathbreaking description of the creation and expansion of social insurance in Costa Rica (1979, 1981). Conducted with a statecentric approach, his study identifies the bureaucracy as the driving force behind social insurance. As we break down the analysis of the policy process into stages, we dispute the bureaucracy's central role regarding agenda setting and adoption. Furthermore, Rosenberg's study focuses almost exclusively on the interests held by domestic actors. We show instead the prominent role of international ideas with which actors interacted.

Our empirical analysis focuses on the role of the state and social actors. A small circle of experts, equipped with political support and relying on international policy prescriptions, were particularly important in delineating the initial architecture of Costa Rica's social insurance. Drawing on the literature about the recent neoliberal period, we refer to these actors as technopols because they have expert knowledge but also "function effectively in bureaucratic battles as well as in the rough-andtumble of political life" (Domínguez 1997, ix). Yet contrary to contemporary views (Joignant 2011), we do not assume that technopols need to occupy formal positions as ministers or vice ministers. Instead, we define them by the four assets they bring to the policy process. First, they have close access to top decisionmakers, and receive full support from them. Second, they are politically savvy, capable of identifying potential vetoes and engaging with them. Even if, in Costa Rica, social vetoes were weak, technopols still had to manage them effectively; the objective was to adapt the design of the program to accommodate different demands without harming its building blocks. 
Third, like technocrats, they use "their claim to knowledge (as opposed to representation or authoritarian rule) to affirm their right to rule" (Centeno and Silva 1998 , 2). Fourth, and particularly important, much of their influence comes from their access to foreign experiences, ideas, and models (Weyland 2004). They acquire ideas from abroad, translating them into domestic conditions. Their participation in networks of people and organizations, in conferences, and in publications contributes to the spreading of shared norms (Sugiyama 2011). ${ }^{2}$

The foundation of social insurance did not result in a universal program overnight, but created a set of policy legacies that contributed to shaping its subsequent trajectory. Policy legacies are influential because they define a path (Pierson 2000); as Pribble explains, they create a set of problems that need resolution in the future - and also, we would add, a set of opportunities. Policy legacies also structure "the distribution of power within the policy sector ... emboldening some groups, while weakening others" (Pribble 2013, 27).

\section{The 1941 Law: Agenda Setting ANd Policy Adoption}

Agenda setting, policy adoption, and policy implementation are three distinct stages of the policy process: the framing of the problem policy seeks to solve, the formal enactment of solutions, and their implementation. These stages often overlap; they are not always coherent; and they usually lead to a nonlinear and messy policy process. In this analysis, we neither expect a mechanical sequence across stages nor give the policy process explanatory power, but we treat it as an analytical tool to evaluate the roles of different actors. ${ }^{3}$

\section{Agenda Setting}

Why did social insurance end up at center stage of the policy agenda in Costa Rica in the early 1940s? How did the overall concern with social insurance translate into a specific design that went beyond traditional Catholic ideas of income maintenance through social insurance for high-income formal workers? Dominant explanations have focused on electoral competition (Molina 2008), visionary leadership (SeguraUbiergo 2007, 208), or domestic, nationally contained policymakers (Rosenberg 1983). Yet by themselves, these explanations are insufficient.

Electoral competition did create the appropriate environment for the reforms. The arrival of President Calderón, Costa Rica's first Social Catholic president in the twentieth century, put a renewed accent on the "social question." Following key encyclicals written by Popes Leon XII and Pius XI, including Quadragesimo Anno (Pius XI 1931), Social Christians worldwide were pushing for social insurance as a policy instrument to avoid class conflict and achieve social peace. ${ }^{4}$ Partisan affiliation therefore made President Calderón partial to state intervention in social affairs. Calderón was also responding to the increasing influence of the Communist Party, which had grown since its creation in 1931 from 5 percent of the electorate in 1934 
to 10 percent in 1940 (Molina 2007). With its daily newspaper, increasing union strength, reformist policy program, and representation in Congress and local governments, the party reshaped and gave new prominence to the social agenda (Molina 2007, 10).

Yet Calderón's election and the growing concern with the social question cannot by themselves explain the growing attention to social insurance. Only once during his candidacy, on the night before the elections, did Calderón address social insurance publicly (Creedman 1994). Molina (2007) says that Calderón did not mention this issue so as to avoid a needless confrontation with the oligarchy. However, we found no evidence in any of the newspapers we collected that social insurance was a social demand posed by bottom-up pressures; these, instead, revolved around basic labor rights (see also Rosenberg 1981). Moreover, during the first year of the new administration, the social question was reflected in the public delivery of goods (e.g., shoes to the poor), while the social insurance project was far from designed.

Therefore, to understand why social insurance entered the policy agenda and why it did not just involve high-income workers as elsewhere, we must turn to the role of a group of advisers close to the president. These technopols were mostly physicians and lawyers (Rosenberg 1981; Molina 2008). Most of them had studied in France or Belgium just before World War I or during the interwar period. They were familiar with Communist, Fascist, and Catholic debates about the role of the state in nourishing class collaboration. They were also well informed about changing regional and international debates on social insurance. Regardless of their political trajectory, they all had the president's ear, and each of them, mostly individually, maneuvered in the policy space the president granted them in various areas, such as public health, labor policy, and social insurance. Across these policy areas, technopoliticians plugged Costa Rican policy formation into an international environment, designing a project that reflected international prescriptions (Secretaría de Gobernación 1941).

International ideas should be considered at two levels: the global policy environment regarding social insurance and the mechanisms through which Costa Rican technopols acquired policy ideas. While it initially supported the expansion of social insurance through the creation of multiple, occupationally based funds, by the mid1930s the ILO also identified the establishment of a single fund mandatory for all workers as a second path (International Labor Review 1936, 654). In fact, in the early 1940s, Oswald Stein, a leading expert at the ILO based in Geneva, fully endorsed a unified system as the best way to expand social insurance (Seekings 2010).

While the ILO shaped the global policy environment and legitimated some national experiences more than others, it had scant direct influence on the policy architecture of Latin American social insurance systems. It certainly did not influence Costa Rica's government or its technopols directly. Between the mid-1920s and mid-1940s, Costa Rica was the only Latin American country that was not a member of the ILO. 5 Technopoliticians were therefore minimally exposed to the organization's ideas directly. Moreover, latecomers like Costa Rica were crafting social insurance schemes at a time when the ILO was fleeing from Nazi Europe to Canada and was less capable of providing technical advice. 
Instead, international ideas arrived in Costa Rica through technopolitical learning in Chile. Years earlier, Calderón's advisers had established close ties with individuals who by now were top Chilean officials. For example, the Costa Rican minister of health, Mario Luján, and Calderón's technical adviser, Guillermo Padilla, a lawyer who had studied in France and previously had directed the National Child Welfare Board, had met Miguel Etchebarne while studying in France in the 1920s. By 1941, Etchebarne was head of the Chilean social insurance agency. ${ }^{6}$

Padilla traveled to Chile in 1941 and wrote the first draft of the social security law in Santiago. The trip influenced the characteristics of the draft through several channels. Padilla met with key Chilean experts. In addition to Etchebarne and actuaries involved in the day-to-day operations of the social insurance fund, Padilla discussed matters with Moisés Poblete Troncoso, a prominent Chilean technopol. A lawyer by training, Poblete had led a failed push to create a fully unified social security system in the mid-1920s (Borzutzky 2002). He was later recruited by the ILO, and at the beginning of 1940 toured Central America, visited Costa Rica, and even met presidential candidate Calderón, among other leaders with whom he discussed the possibility of Costa Rica's rejoining the ILO (Poblette Troncoso 1940).

Chilean experts like Poblete were at the heart of debates on how to build social insurance. In 1936 they had hosted the ILO-sponsored Labor Conference of American States, which recommended that social insurance be compulsory, be extended to all workers (salaried or not), and seek to prevent, cure, and manage social risks. Governments were advised to establish wage limits exempting the better-off from social insurance (International Labor Review 1936, 654).

Padilla also learned from the Chilean Seguro Obrero and its failures. In his own words years later, "[from the Chilean experience I learned] the need to apply social insurance in an integral way to prevent the dispersion of similar funds that suddenly become antagonistic and also the need to give a strong economic support to the institution to secure stability" (Padilla 1966, 30). Although no records of these exchanges were left, it is likely that these lessons came directly from Poblete.

Chilean experts also put Padilla in contact with Oswald Stein, the ILO chief of social security and probably the most important global expert on social security matters. Stein arrived in Chile in 1941, only a few weeks after Padilla had returned to Costa Rica. Poblete, then the ILO's Chilean correspondent, shared Padilla's draft with Stein, who read it and sent a letter to Padilla. In his letter, Stein congratulated Padilla for a project that, "echoing the experiences of other countries, particularly Chile and Peru, provides innovative solutions ... adapted to the particular prevailing conditions in the country" and said he wished to follow the policy process closely. He also offered to make available cross-national lessons that could further contribute to Costa Rica's design process (CCSS 1943, 2).

When the law was introduced in Congress, the Chilean influence was recognized by its author: "we do not aim at making this an innovative project. Guidelines ... we propose are the same all over the place" (Secretaría de Gobernación 1941, 1). The influence of external experiences and contacts was stressed again once the system was in place (e.g., CCSS 1943). 


\section{Policy Adoption}

Under the close supervision of President Calderón, Padilla, accompanied by other prominent technopols, was heavily involved in the legislative process. Legislator Ernesto Marten, with close ties to the president, also played an important role in mediating relations between Congress and the executive (Rosenberg 1983). Political parties did not have much influence during this stage; legislators left untouched the overall orientation and most policy instruments as proposed in the draft. Moreover, all specific matters concerning implementation were left to the new board. Postponing controversial matters (including the implementation date of health insurance and when and how rural workers were to be insured) and turning them into a sequence of future decisions proved to be effective in buffering potential conflicts.

Civil society played a minimal role in the legislative process and seldom questioned the basic architecture of social security. Through Trabajo, the Communist Party called on "the Costa Rican people" and the "working class" to mobilize around social security and the "progressive attitude" of the Costa Rican president (Trabajo 1941). Yet no newspaper provides evidence of mobilizations actually occurring, and the party never made relevant suggestions in terms of content. Newspapers also indicate that only official actors, mostly bureaucrats and appointed officials, were called to the commission (Congreso Constitucional 1941a, b; La Tribuna 1941b).

The only explicit request to be spared from joining the new system came from the judiciary. The bill established that all special pension regimes would be maintained but that the newly hired would enter the unified system (Congreso Constitucional 1941b; Diario de Costa Rica 1941). The judiciary saw this as a threat to the financial sustainability of its special fund and argued that such a special fund was consistent with the independence between powers.

Meanwhile, business did not act in an organized fashion, nor did it lobby against social insurance. We reviewed the three main Costa Rican newspapers in search of the private sector's official position but could not find any for the period 1941 to 1943 . The progovernment Tribuna provided only a few articles with comments from entrepreneurs, and they generally present supporting statements from specific companies (Tribuna 1941a, 1942c). The opposition newspaper does not have any reference either in favor or against. Even the United Fruit Company indicated its willingness to pay social insurance for the workers in its manufacturing activities in Costa Rica (Diario de Costa Rica 1942a).

The overall lack of policy influence coming from pressure groups clearly contrasts with the situation in the Southern Cone and probably facilitated the passing of the law without any major changes. Yet it is also important to recognize that proponents of social insurance displayed political skills that prevented and managed vetoes. Wage ceilings reassured physicians - traditionally opposed to public health in Latin America because of its effects on the number of clients- that social insurance would not threaten their liberal practice (Rosenberg 1981). During the legislative process, the wage ceiling was established at 1941 US\$50 per month, 17 dollars below the ceiling initially drafted in the bill. By the same token, the initial exclusion 
from social security of all employees who worked fewer than 180 days per yearwhich was the case of many coffee laborers, particularly on small and medium-sized plantations—eased business opposition.

\section{Policy Implementation}

In most peripheral countries, the transformation of laws into actual policies is riddled with difficulties. Lack of resources and of capable bureaucracies can render new programs totally ineffective. Influential collective actors may seek to retailor the new programs in light of their own interests, while a majority of the population remains uninterested or even opposed to the policy, as in Peru in the 1930s, Mexico in 1943, and Guatemala in 1946 (Dion 2010; Mesa-Lago 1978; Rosenberg 1981).

Again, Costa Rica may have benefited from the relative weakness of actors that could have tried to torpedo social insurance. A significant part of the traditional coffee elite, which either was German or had ties to German families, was weakened by the domestic reflection of global geopolitical changes (Shifter 1979). Urban service and manufacturing firms were soon affected by the creation of social insurance. Yet their relative economic weight was limited and their mobilization capacity unimpressive. The Chamber of Industries was not created until 1943, after the actual approval and implementation of social insurance. Opposition to the government intensified only a few years later when the number of business-led strikes in urban areas increased, but they generally focused on other policy measures, like the Labor Code and the Social Guarantees (Yashar 1997).

In fact, at this stage, prominent civil society actors actually endorsed the government's proposal to create social security. In particular, the Catholic Church and the Communist Party, at that time part of the governing coalition, had a role in shaping a public opinion favorable to social insurance. For example, on a request from the president of the republic, in April 1942 the Catholic archbishop of San José published a pastoral letter-intended to be read in every single church across the country during Sunday mass-titled "The Catholic Church Supports Social Insurance" (Arrieta 1982). Social insurance led the Communist Party to reassess the government and recognize its capacity to introduce progressive policies. Trabajo, the official party newspaper, devoted a considerable number of articles to arguing how important supporting healthcare insurance was for the working class.

The Communist newspaper also praised employers "who are excellent and pay" but encouraged union delegates to take a close interest in overseeing payroll taxes (e.g., going to the capital city, San José, to double-check that employers had indeed transferred contributions on behalf of all workers) (Trabajo 1942b). This effort coincided with the launch of a CCSS campaign against noncompliance among employers, which stressed sanctions and praised dutiful employers (Diario de Costa Rica 1942b).

This support does not mean the absence of vetoes. A few groups of workers, including public employees of the capital's municipal government, a public bank, and customs, demanded protection for their special status. They succeeded in pro- 
tecting and even increasing the number of special pension regimes. Still, an overwhelming majority of workers ended up insured under the single collective fund created under the CCSS and, in the long run, all but two additional regimes remained in place. ${ }^{7}$

Technopols also played important roles at the implementation stage. Those in leading positions on the brand-new social insurance board-including Padilla, who was initially second in command and constantly utilized his ties to the president (CCSS 1942a)—confronted any potential opposition by broadening social support through the swift expansion of benefits. Just a few months after launching services, the largest hospital in the country was looking after an average of 25 insured people per day (Trabajo 1943a). By December 1942, the insured rose to 14,000 (out of an estimated 227,583 labor force), and more than 10 percent $(1,500)$ were receiving healthcare services provided by the new agency (CCSS 1942b). Eight physicians hired by the social insurance agency worked on facilities overseen by the Ministry of Public Sanitation and prescribed medicines available there or in private pharmacies (Rosenberg 1983). Services were initially provided to workers residing in the four largest cities in the Central Valley, but by the end of 1943, services had already reached two small towns as well. ${ }^{8}$

Technopols filled key initial positions created by the new CCSS—officials who later drove a rapid deployment of institutional resources. Padilla recalled them as "progressive students" at the School of Law (Rosenberg 1983). They ran two critical departments, one charged with explaining the benefits of social insurance (CCSS $1943,141)$, the other with collecting payroll taxes. Postponing the launching of oldage insurance, the new agency set payroll taxes below the legal limit (Trabajo 1942b). While the first contributions were collected, funding for the social security agency was drawn from increased taxes on beverages (La Tribuna 1942b) in the considerable amount of US $\$ 177,000$ for the first 12 months.

Just two years after the approval of the founding law, the CCSS was able to overcome congressional opposition to two critical matters: expanded eligibility and further degrees of institutional autonomy. The law was an initiative of the Caja leadership and was backed by high-level ILO experts. It established coverage for all manual and white collar salaried workers, framing this decision as necessary for the long-term financial sustainability of social insurance. The law also secured financial and managerial autonomy from the executive (Secretaría de Gobernación 1943). Such autonomy had been initially established in the presidential draft sent to Congress in 1941 but was later removed, so that all decisions made by the social insurance board were overseen by an external body. The reform was barely debated publicly or even mentioned more than once or twice in newspapers. ${ }^{9}$ 


\section{The INCREMENTAL Move TOWARD UNIVERSALISM}

After the reforms of the early 1940s, Costa Rica gradually moved toward universal health services and pensions. Several factors contributed to this positive trajectory. Intense electoral competition and ideological commitment to social development supported the growth of social spending; this was particularly clear in the early 1960s when the PLN, then in the political opposition, proposed a constitutional reform that required universal coverage for salaried workers. The amendment allegedly aimed to strengthen the link between the PLN and social security-still seen as Calderón's program - in the eyes of the electorate (Legislator 2011). Costa Rica's unique success at promoting formal employment also contributed to the expansion of social services by providing resources and increasing the number of those legally entitled to social security-a point we have discussed elsewhere (Martínez Franzoni and Sánchez-Ancochea 2013).

Yet the legacies of the architecture established during the foundation stage played a particularly important role. Drawing on Pribble's 2013 conceptualization, table 1 summarizes the main features of the policy architecture and the path this architecture set.

While the distinction between different features may be analytically convenient, in reality they were closely intertwined. This is clear when considering key policy instances in the early 1960s and the early 1970s. In 1960, the CCSS bureaucrats argued that the financial sustainability of social insurance was at stake due to the combined pressures of growing service demand and government debt (Rosenberg 1983). Given the unified character of social insurance, the officials did not request the creation of new social insurance funds. Instead, they focused on the expansion of the wage ceiling, which would affect relatively high-wage earners. It was in response to these bureaucratic demands that the PLN proposed the universalization of social insurance in ten years and the elimination of all wage ceilings.

Coverage expanded gradually during the 1960s-from 15 percent in 1960 to 38 percent in 1970 (Mesa-Lago 1985) — but shortages in revenues persisted. By the early 1970s, the Caja bureaucrats were pushing for the elimination of the wage ceilings to increase revenues and fund the required universalization of the system. Discussing the budget for 1970 in a meeting of the Management Board of the Caja, the Auditor General of social insurance said, "we must insist on the increase in the wage ceiling for the Maternity and Sickness insurance, since this will provide the necessary additional income," and added that this measure would be significantly more effective than what the government was proposing at the time; namely, transferring taxes on cigarettes, which expanded slowly (CCSS 1969).

The elimination of the wage ceiling would increase payroll taxes for an estimated 5 percent of workers making more than the equivalent of US\$151 per month (MEIC/Dirección General de Estadística y Censos 1968) and would also force them to become members of social insurance. ${ }^{10}$ This tax increase received ample support from trade unions. Newspapers reported 18 unions and federations expressing their 
Table 1. The Implications of Policy Legacies for Universal Expansion, 1950-1980

\begin{tabular}{|c|c|c|}
\hline Policy Feature & Problem/Opportunity & Consequence \\
\hline \multirow[t]{2}{*}{$\begin{array}{l}\text { Bottom-up expansion of } \\
\text { mandatory social insurance } \\
\text { for salaried workers }\end{array}$} & $\begin{array}{l}\text { Financial constraints to meet } \\
\text { the growing demand for } \\
\text { services }\end{array}$ & $\begin{array}{l}\text { Leads to lifting and } \\
\text { eventually eliminating wage } \\
\text { ceilings }\end{array}$ \\
\hline & $\begin{array}{l}\text { Most workers already insured } \\
\text { would benefit from vertical } \\
\text { expansion }\end{array}$ & $\begin{array}{l}\text { Most workers and trade } \\
\text { unions support the } \\
\text { elimination of wage ceilings }\end{array}$ \\
\hline \multirow[t]{2}{*}{$\begin{array}{l}\text { Creation of a top-down } \\
\text { unified system under a } \\
\text { single agency }\end{array}$} & $\begin{array}{l}\text { High investment in new } \\
\text { medical facilities }\end{array}$ & $\begin{array}{l}\text { In the absence of competing } \\
\text { private services, white } \\
\text { collar workers and the } \\
\text { better-off have incentives to } \\
\text { join the system }\end{array}$ \\
\hline & $\begin{array}{l}\text { Powerful bureaucracy gains } \\
\text { policy influence }\end{array}$ & $\begin{array}{l}\text { Bureaucratic demands push } \\
\text { for an expansionary } \\
\text { dynamic }\end{array}$ \\
\hline $\begin{array}{l}\text { Payroll taxes as primary } \\
\text { funding source }\end{array}$ & $\begin{array}{l}\text { Effective income-raising } \\
\text { mechanism }\end{array}$ & $\begin{array}{l}\text { Further expansion is } \\
\text { managerially easy even to } \\
\text { fund noncontributory access }\end{array}$ \\
\hline
\end{tabular}

Source: Authors' elaboration

views to the legislative commission and only one opposing the measure (La Nación 1971b-jj; Prensa Libre 1971a-y). Policy legacies partly explain their support, since the program was built from the bottom up: from the outset, Costa Rican workers who were already insured had incentives to support further expansions to higherincome groups that would bring larger tax contributions to the system. This contrasts with the experience in other Latin American countries, where high-income groups (and the military), which were first incorporated, forced the vertical rather than horizontal expansion of programs, thus preventing lower-income groups from receiving the same services (Filgueira 2007).

Although high wage earners were harmed by the reform, the provision of highquality services made their incorporation into the system attractive. ${ }^{11}$ As the Caja built new hospitals, its facilities became the newest and best funded and equipped. According to the minister of health between 1970 and 1974, José Luis Orlich, "on the one hand, the Caja has good medical treatment thanks to its great facilities and good personnel, which defines a high-quality medicine. On the other hand, the Ministry has extremely poor facilities [and] deteriorated buildings so that we cannot talk about good medicine" (La Nación 1971a). ${ }^{12}$ With the removal of wage ceilings and the expansion of the proportion of workers under mandatory insurance, coverage expanded rapidly to reach 55 percent in 1975 and 85 percent in 1980 (MesaLago 1985). 
Of course, the government could have increased other taxes to fund the social insurance shortages. Yet payroll taxes were well established, had less political opposition, and were easier to increase. When addressing the funding of a new, large social program in the early 1970s, the minister of labor argued, "we have determined that in our country the only secure way is through payroll taxes and through the subsequent administration by the Caja due to the collecting systems already established ... and the experience administering social insurance" (CCSS 1972). Meanwhile, expanding general taxation proved much harder, due to strong social opposition; by 1970, Costa Rica's tax burden was just 12 percent of GDP compared to 15 percent in the poorer Dominican Republic.

\section{CONCLUSIONS AND IMPLICATIONS}

In the early 1940s, Costa Rica adopted a social insurance system that became the foundation of its universal social policy. The system expanded along lines of income and class rather than occupation and created a basic floor of benefits among the lowand lower-middle-income workers. Later on, higher income groups were also brought on board, in sharp contrast to the rest of the region, where social insurance was from the outset tailored to the preferences of various middle-class groups.

Much of the literature on social policy in the periphery focuses on the influence of democracy and interest groups. According to this view, Costa Rica's successful performance can be explained by the combination of a strong democracy and weak interest groups. While acknowledging the importance of these macrofactors, we have argued that they cannot, by themselves, account for the adoption of the policy features that later drove social policy toward universalism.

By way of placing new concerns (i.e., the social question) on the political agenda, democratically elected political leaders created opportunities for new policies. Yet political leaders seldom drove the architecture involved in new policies; they just gave technopoliticians access to the policy process. Technopoliticians comfortably interacted with politics, the technical aspects of the architecture involved, and international policy prescriptions. They became intermediaries and translators of international ideas, drawing on them to shape policy debates and policy design. Last but not least, technopols contributed to effectively managing vetoes from interest groups, which, although weaker than in the Southern Cone, did exist. Combining macrofactors with a detailed analysis of the actors in the policy process, this article has sought to fill in the missing link between democracy and universalism.

Similar to what is shown by research on more recent policy reforms (Domínguez 1997; Weyland 2004), we suspect that back in the foundational stages of social policy in the region, the presence of technopols was not unique to Costa Rica. What was indeed unique to this country was the fortunate combination of socially conscious politicians who gave space to progressive technopols; international ideas that favored more universal architectures for social insurance; and a politically savvy management of vetoes through a gradualist strategy. 
What lessons does Costa Rica bring to our understanding of social policy elsewhere? What clues can we draw to the renewed contemporary search for universalism? Our research makes a threefold contribution. First, it stresses the extraordinary significance that initial policy architectures have for subsequent trajectories. These include decisions regarding the design that policy ultimately takes, as well as decisions regarding the process, incremental or not, to get there. Second, the prominence our analysis grants to international ideas constitutes good news for the prospects of universalism in Latin America and other peripheral countries today. After decades of promoting residual approaches to social policy, a growing number of international institutions have revisited universalism (ILO 2011; UNRISD 2010), and many Latin American parties in power are paying attention to it (Martínez Franzoni and Sánchez-Ancochea 2012). Third, we need to give careful consideration to actors that combine expertise and political connections to move progressive policy designs forward in democratic contexts. Identifying these actors, their approach to state building and social policy, and the sources of their ideas should give us a more comprehensive picture of the potential for change in Latin America and other parts of the developing world.

\section{Notes}

We thank Fabrice Lehoucq, Andrew Schrank, John Stephens, Kurt Weyland, four anonymous LAPS reviewers, and fellow participants on panels held at the Kellogg Institute for International Studies, the Latin American Studies Association conference in Toronto, the University of Costa Rica, and the University of Oxford, for comments on previous versions of this article. We also acknowledge support from the British Academy, Desigualdades-net, the Fulbright Program for Central American Scholars, and the Kellogg Institute for International Studies. Sara Acuña Avalos in Chile and Diana León Espinoza and Héctor Solano Chavarría in Costa Rica provided valuable support with fieldwork and data analysis.

1. The few developing countries with vibrant democratic institutions also tend to have a free and critical press and active social movements that demand better services.

2. Technopols differ from Weberian bureaucrats. The latter are experts with careers in the civil service and not wholly in the hands of their political superiors. While bureaucrats may claim expertise on policy affairs, their primary source of legitimacy is their place in the hierarchy.

3. Some studies seek to explain issue framing regardless of its success in entering the policy process (see, e.g., Blofield and Haas 2013), but most studies consider issue framing as part of the analysis of agenda setting (see, e.g., Birkland 2011). In the following discussion, we follow this dominant approach but also emphasize that issue framing and agenda setting are part of an iterative process.

4. In this sense, Calderón should not be seen as an isolated leader, and social insurance should not been seen as his "almost personal project" (Segura-Ubiergo 2007, 208). Calderón was part of a changing world dominated by struggles between Christian Democrats and Communists.

5. Costa Rica was a member from 1920 to 1927. It participated as an observer after 1936 and rejoined the organization as a member in 1944 (ILO n.d.).

6. Etchebarne finished medical school in Paris in 1928. By 1938 he was minister of health as part of the Popular Front government. In December 1939, when Salvador Allende 
took over that position, Etchebarne became chief of social insurance (Diccionario biográfico de Chile 1942).

7. Local governments had different views (La Tribuna 1942a; Diario de Costa Rica 1942c, d). The social insurance agency opposed segmentation (Diario de Costa Rica 1942e), as did public opinion (see Diario de Costa Rica 1942e). Newspapers provide evidence concerning the prominence of the single fund (e.g. La Tribuna 1942c; Diario de Costa Rica 1943a).

8. This expansion reflected collective action demanding that social insurance be expanded to locations other than the capital city (Trabajo 1942a, 1943b; Diario de Costa Rica $1943 b, c)$.

9. Unions supported this measure as one badly needed for social insurance to accomplish its goals (Diario de Costa Rica 1943d).

10. For pensions the wage ceiling was lower, and was not eliminated until later.

11. An anonymous full-page advertisement estimated that for workers making more than one thousand colones per month, the annual payroll contributions would surpass a monthly salary (La Hora 1970).

12. In 1972, the Caja had 1,265 beds and was responsible for 22 percent of the patients attended, compared to 5,984 and 78 percent in the public hospitals (Benavides 1972).

\section{REFERENCES}

Arrieta, Santiago. 1982. El pensamiento politico social de monseñor Sanabria. San José: EDUCA.

Benavides, Carmona. 1972. Testimony. Comisión de Asuntos Sociales, Audiencia JPS/SJ 117-1972 and 13-7-1972.

Birkland, Thomas. 2011. An Introduction to the Policy Process: Theories, Concepts, and Models of Public Policy Making. New York: M. E. Sharpe.

Blofield, Merike, and Liesl Haas. 2013. Policy Outputs. In The Oxford Handbook of Gender and Politics, ed. Georgina Walden, Karen Celis, Johanna Kantola, and S. Laurel Weldon. New York: Oxford University Press. 703-25.

Borzutzky, Silvia. 2002. Vital Connections: Politics, Social Security, and Inequality in Chile. Notre Dame: Notre Dame University Press.

Caja Costarricense del Seguro Social (CCSS). 1942a. Acta 1. January 23.

- 1942b. Acta 109. December 11.

1943. Untitled article. Su Seguridad: Revista Oficial de la Caja Costarricense de Seguro Social 7 (October-November-December): 2. San José: CCSS.

1969. Acta 4545. November 6.

1972. Acta 4468. May 30.

Centeno, Miguel, and Patricio Silva. 1998. The Politics of Expertise in Latin America. London: Macmillan.

Collier, David, Henry Brady, and Jason Seawright. 2010. Sources of Leverage in Causal Inference: Toward an Alternative View of Methodology. In Rethinking Social Inquiry: Diverse Tools, Shared Standards, ed. Brady and Collier. Lanham: Rowman and Littlefield. 229-71.

Congreso Constitucional de la República de Costa Rica. 1941a. Comisiones del Congreso, Dictamen de Creación de la Caja de Seguro Social. October 16.

—. 1941b. Decreto de Creación de la Caja de Seguro Social. October 31.

Creedman, Theodore. 1994. El gran cambio: de León Cortés a Calderón Guardia. San José: Editorial Costa Rica. 
Diccionario biográfico de Chile. 1942. Miguel Etchebarne. Santiago: La Nación SA.

Dion, Michelle. 2010. Workers and Welfare: Comparative Institutional Change in Twentiethcentury Mexico. Pittsburgh: University of Pittsburgh Press.

Domínguez, Jorge. 1997. Technopols: Freeing Politics and Markets in Latin America in the 1990s. University Park: Penn State University Press.

Filgueira, Fernando. 2007. The Latin American Social States: Critical Juncture and Critical Choices. In Democracy and Social Policy, ed. Yusuff Bangura. New York: Palgrave/UNRISD. 136-63.

Haggard, Stephan, and Robert Kaufman. 2008. Development, Democracy, and Welfare States: Latin America, East Asia, and Eastern Europe. Princeton: Princeton University Press.

Huber, Evelyne, and John Stephens. 2012. Democracy and the Left: Social Policy and Inequality in Latin America. Chicago: Chicago University Press.

International Labour Organization (ILO). 2011. Report IV. Floor of Social Protection for Social Justice and Equitable Globalization. ILC.101/IV/1. International Labour Conference, 100th meeting, 2011. Geneva: ILO.

—. n.d. NATLEX database. http://www.ilo.org/dyn/natlex/natlex_browse.home. Accessed January 2011.

International Labour Review. 1936. The Labour Conference of the American States which are Members of the International Labour Organisation. 33, 2: 446-684.

Joignant, Alfredo. 2011. The Politics of Technopols: Resources, Political Competence and Collective Leadership in Chile, 1990-2010. Journal of Latin American Studies 43: 51746.

Legislator. 2011. Prominent legislator who supported the constitutional mandate to universalize social insurance among salaried workers by 1971. Author interview. San José, August 10.

Lehoucq, Fabrice. 2010. Political Competition, Constitutional Arrangements, and the Quality of Public Policies in Costa Rica. Latin American Politics and Society 52, 4 (Winter): 53-77.

Lewis, Colin, and Peter Lloyd-Sherlock. 2009. Social Policy and Economic Development in South America: An Historical Approach to Social Insurance. Economy and Society 38, 1: 109-31.

Mahoney, James. 2010. After KKV: The New Methodology of Qualitative Research. World Politics 62, 1: 120-47.

Martínez Franzoni, Juliana, and Diego Sánchez-Ancochea. 2012. The Double Challenge of Market and Social Incorporation. Working Paper no. 27. Free University of Berlin: Desigualdades, International Research Network on Interdependent Inequalities in Latin America.

. 2013. Can Latin American Production Regimes Complement Universalistic Welfare Regimes? Latin American Research Review 48, 2: 148-73.

McGuire, James. 2010. Wealth, Health and Democracy in East Asia and Latin America. Cambridge: Cambridge University Press.

Mesa-Lago, Carmelo. 1978. Social Security in Latin America: Pressure Groups, Stratification, and Inequality. Pittsburgh: University of Pittsburgh Press.

. 1985. Health Care in Costa Rica: Boom and Crisis. Social Science and Medicine 21, 1: 13-21.

Ministerio de Economía y Comercio (MEIC) and Dirección General de Estadística y Censos. 1968. Encuesta de hogares por muestreo (julio de 1966 a junio de 1967). San José: MEIC. 
Molina, Iván. 2007. Anticomunismo reformista. San José: Editorial Costa Rica. 2008. Los pasados de la memoria: el origen de la reforma social en Costa Rica (19381943). Heredia: EUNA.

Padilla, Guillermo. 1966. El seguro social en Costa Rica: su origen y sus primeros cinco ańos. La Nación, December 10: 30, 31, 90.

Pierson, Paul. 2000. Increasing Returns, Path Dependence, and the Study of Politics. American Political Science Review 94, 2: 251-67.

Pius XI, Pope. 1931. Cuadragesimo Anno: On Reconstruction of the Social Order. Vatican: Libreria Editrice Vaticana.

Poblette Troncoso, Moisés. 1940. Rapport mission en Amérique Central. Report 10/515/40. January 20. Santiago de Chile: ILO.

Pribble, Jennifer. 2011. World Apart: Social Policy Regimes in Latin America. Studies in Comparative International Development 46: 191-216.

2013. Welfare and Party Politics in Latin America. Cambridge: Cambridge University Press.

Rosenberg, Mark B. 1979. Social Security Policymaking in Costa Rica: A Research Report. Latin American Research Review 14, 1: 116-33.

- 1981. Social Reform in Costa Rica: Social Security and the Presidency of Rafael Calderón Guardia. Hispanic American Historical Review 61, 2 (May): 278-96.

1983. Las luchas por el seguro social en Costa Rica. San José: Editorial Costa Rica.

Sandbrook, Richard, Marc Edelman, Patrick Heller, and Judith Teichman. 2007. Social Democracy in the Global Periphery: Origins, Challenges, Prospects. Cambridge: Cambridge University Press.

Secretaría de Gobernación, Policía, Trabajo y Previsión Social. 1941. Letter to Congress. July 15. San José: Archivo Asamblea de la Legislativa.

1943. Letter to Congress. n.d. San José: Archivo Asamblea de la Legislativa.

Seekings, Jeremy. 2010. The ILO and Welfare Reform in South Africa, Latin America, and the Caribbean, 1919-1950. In ILO Histories: Essays on the International Labour Organization and Its Impact on the World During the Twentieth Century, ed. Magaly Rodríguez, Jasmien Van Daele, Geert Van Goethem, and Marcel van der Linden. Bern: Peter Lang. 145-73. Segura-Ubiergo, Alex. 2007. The Political Economy of the Welfare State in Latin America: Globalization, Democracy and Development. Cambridge: Cambridge University Press.

Shifter, Jacobo. 1979. La fase oculta de la guerra civil. San José: EDUCA.

Sugiyama, Natasha Borges. 2011. The Diffusion of Conditional Cash Transfer Programs in the Americas. Global Social Policy 11, 2-3: 250-78.

United Nations Research Institute for Social Development (UNRISD). 2010. Combating Poverty and Inequality: Structural Change, Social Policy and Politics. Geneva: UNRISD.

Weyland, Kurt. 2004. Conclusion. In Learning from Foreign Models in Latin American Policy Reform, ed. Weyland. Washington, DC: Woodrow Wilson Center Press. 241-83.

Yashar, Deborah J. 1997. Demanding Democracy: Reform and Reaction in Costa Rica and Guatemala, 1870s-1950s. Stanford: Stanford University Press. 


\section{NeWspaper ARTICLES}

Diario de Costa Rica (San José). 1941. Previstos todos los aspectos de la implantación de los seguros sociales en Costa Rica. October 2: 1, 6.

. 1942a. La United Fruit Company pagará el seguro social en sus actividades bananeras en Costa Rica. March 11: 1, 5.

1942b. Anuncio CCSS. September 18: 5.

1942c. La Municipalidad de Cartago pide al Congreso no aprobar la reforma al Artículo 43 de la Ley de Seguro Social. August 5: 1, 8.

1942d. La Municipalidad de Heredia, en sensacional acuerdo, se pronuncia en contra de la Ley de Pensiones Municipales y a favor del Seguro Social. July 30: 1, 6.

- 1942e. La Caja Costarricense de Seguro Social expone las razones que tiene para oponerse al Proyecto de los Empleados Municipales, tendiente a que se les exima del Seguro Social. July 21: 3 .

- 1943a. Los empleados de aduanas piden ley especial de pensiones. August 2: 9.

- 1943b. Puntarenas también rendirá homenaje al autor de las Garantías Sociales. September 2: 2 .

- 1943c. Puntarenas: base inconmovible del Código de Trabajo. September 9: 2.

- 1943d. Las organizaciones obreras y campesinas del país apoyan el Proyecto de Reforma a la Ley del Seguro Social. September 5: 13.

La Hora (San José). 1970. Médicos satisfechos por solución a crisis. July 28: 3.

La Nación (San José). 1971a. Sistema unificado de salud. February 24: 57.

—. 1971b. Cautela ante la universalización. March 9: 12. 1971c. Ruptura de topes es perjudicial. March 9: 16.

. 1971d. Estamos de acuerdo con la ruptura de topes en el Seguro Social. March 10: 13.

1971e. Incluir a estudiantes mayores de dieciocho años en el Seguro Social. March 10: 18 .

— 1971f. La clase trabajadora debe respetar y apoyar la ruptura de topes. March 12: 28. 1971g. Quién paga los beneficios sociales. March 13: 57.

. 1971h. Fuerte desembolso a trabajadores con supresión de topes al Seguro. March 14: 32 .

- 1971i. Se puede extender la seguridad social a nuevas zonas del país. March 14: 33.

1971j. El Partido Demócrata Cristiano ante la universalización del Seguro Social. March 14: 37.

. 1971k. Piden aprobar reformas a ley del Seguro Social. March 15: 35.

—. 19711. Luchan porque la ruptura de topes sea gradual. March 16: 1.

—. 1971m. La Constitución obliga a universalizar los seguros. March 16: 1.

_. 1971n. Rompimiento de topes en el Seguro Social. March 16: 19.

1971o. Ley para levantar topes poco a poco. March 17: 2.

—. 1971p. Serios problemas traerá la ruptura de los topes. March 17: 2.

—. 1971q. ¿Por qué el trabajador contribuye al seguro social? March 18: 12.

—. 1971r. La injusticia de eliminar los topes. March 18: 14.

—. 1971s. Insconstitucional ruptura de topes. March 18: 18.

1971t. Apoyo al Seguro Social. March 18: 20.

1971u. En vista de que la Asamblea Legislativa está conociendo el proyecto de ley que tiene el propósito de eliminar los topes de contribución al Seguro Social. March 18: 22 . 
1971v. Trabajadores de Juan Viñas apoyan ruptura de topes. March 18: 8.

1971w. SITRA en total acuerdo con proyecto de ruptura de topes en el Seguro Social. March 18: 30.

1971x. Caja Costarricense de Seguro Social informa. March 19: 2.

1971y. Quien puede más, que pague más: una falacia. March 19: 14.

1971z. Aprobado Código Tributario. Continúa debate sobre ruptura de topes. March 19: 18.

1971 aa. Fenatra apoya la ruptura de topes. March 20: 8.

- 1971bb. Los asegurados más pobres sufrirán ruptura de topes. March 20: 9.

1971cc. Un Sí categórico a la eliminación de topes. March 20: 12.

1971dd. Asalariados serán víctimas de la eliminación de topes. March 21: 1.

1971ee. Algo sobre la ruptura de topes. March 22: 63.

1971ff. Comité de Lucha pro-Reforma al Código Penal y Legislación Social apoya ruptura de topes. March 23: 8.

—1971gg. Continúa controversia sobre proyectada ruptura de topes. March 23: 18.

1971hh. Cámara de Industrias y ministro Jiménez dialogaron sobre topes. March 23: 27.

1971ii. Caja Costarricense de Seguro Social señala. March 23: 28.

$1971 \mathrm{jj}$. Los profesores del Liceo de Costa Rica, ante el proyecto para la eliminación de los topes del seguro social, se permiten hacer la siguiente manifestación pública. March 24: 24.

Prensa Libre (San José). 1971a. Estamos de acuerdo con la ruptura de topes en el Seguro Social. March 10: 13.

— 1971b. Sindicalismo es medio de desarrollo social. March 11: 1-2.

1971c. Niego mensaje de subversión. March 12: 1-2.

1971d. Lesión seria al desarrollo es la ruptura de topes. March 12: 1, 17.

1971e. No title. March 16: 17.

1971f. No title. March 17: 12.

1971g. CCSS. March 17: 16.

1971h. No title. March 18: 15.

1971i. No title. March 18: 18.

1971j. Eliminación de topes: serie de interrogantes sin respuesta. March 19: 6.

1971k. No me defiendas compadre. March 19: 11.

19711. CCSS. March 19: n. p.

1971 m. Exposición del señor Ministro de Trabajo y Bienestar Social sobre el proyecto de eliminación de topes del Seguro Social. March 22: 4-5.

1971n. CCSS. March 22: 22.

1971o. CCSS. March 23: 17.

1971p. Comité de Lucha pro-Reforma al Código Penal y Legislación Social apoya ruptura de topes. March 23: 8.

—. 1971q. Ruptura de topes no es una amenaza. March 24: 1-2.

1971r. Eliminar topes donde se sirve. March 24: 1-2.

1971s. Eliminación de topes y algunas conclusiones. March 24: 6 .

1971t. Eliminación de topes y algunas conclusiones II. March 25: 6.

1971u. No title. March 25: 18.

1971v. Ruptura: paso trascendental. March 26: 1-2.

1971w. No title. March 26: 2.

1971x. Eliminación de topes y una conclusión final. March 26: 6.

1971y. No title. March 26: 13. 
Trabajo (San José). 1941. De pie la clase trabajadora a luchar por la Ley de Seguro Social. October 18: 1, 4.

- 1942a. Brillante la Jornada del $1^{\circ}$ de Mayo en Puntarenas. May 9: 2,4.

- 1942b. Los Seguros de Enfermedad, Maternidad y Cuota Mortuaria han comenzado a hacerse efectivos. September 12: 3-4.

-1943a. El Seguro Social no es puro cuento. Si no estuviéramos asegurados no podríamos ser atendidos por el médico, dicen los hospitalizados del Seguro Social. February 6: 1, 3.

—. 1943b. Imponente manifestación popular en Turrialba. April 3: 1, 4.

La Tribuna (San José). 1941a. Debemos adaptar en Costa Rica la ley de seguro social no en forma total sino parcialmente. October 21: 1-2.

1941b. Invitada Costa Rica a un congreso interamericano de previsión social. October 22: 1,4 .

- 1942a. Acuerda la Municipalidad de Heredia el ingreso al Seguro Social de todos sus empleados y obreros. July 2: 2 .

- 1942b. Un millón de colones tiene el depósito la Caja del Seguro Social para atender los tres primeros seguros. August 27: 1, 2.

-1942c. El Banco Nacional pide al Ejecutivo excluir a sus empleados de los beneficios del seguro social. September 25: 5 . 